\title{
Hospitalization: A Contentious Issue for Patients and Health Funds in Baden, 1893-1914
}

\author{
SYLVELYN HÄHNER-ROMBACH*
}

Hospitals in Germany had traditionally provided care on a voluntary basis. Before the end of the nineteenth century, hospitalization was compulsory only during epidemics or in the case of infectious diseases such as syphilis or leprosy. Voluntary hospitalization normally occurred only when hospital beds were available, when payment was guaranteed, or during emergencies. Towards the end of the nineteenth century, however, there was a definite increase in hospitalization levels, primarily due to two important developments: the introduction of health insurance in 1883 , and the growing number and size of hospitals. ${ }^{1}$ Health insurance covered its members' hospital expenses, and the hospitals provided facilities for more and more patients.

The Health Insurance Act (Krankenversicherungsgesetz) was passed by the German Reichstag in 1883 , and came into effect on 1 December $1884 .^{2}$ The law introduced compulsory health insurance for workers employed in trade and industry earning no more than a specified wage. The aim was to protect certain groups within the workforce (and their families) from the financial consequences of illness. ${ }^{3}$ To help make health funds more popular, the Act declared them self-governing and, in order to prevent malingering and exploitation, self-regulation was introduced. ${ }^{4}$ The health funds received an average of 4 per cent of each employee's wages (the range was from 1.5 per cent to 6 per cent), twothirds of which came from the worker's wages, and one-third from the employer.

* Sylvelyn Hähner-Rombach, DPhil., Institut für Geschichte der Medizin der Robert Bosch Stiftung, Straussweg 17, 79184 Stuttgart, Germany.

The paper was first written for the Anglo-DutchGerman Workshop 'Patients in history $\left(19^{\text {th }}-20^{\text {th }}\right.$ century)' in Stuttgart, 12-14 July 2001. I owe the participants of this workshop a great deal. Their knowledge and the inspiring discussion led me to further sources and problems. I also would like to thank the referees for their helpful comments, and Martin Dinges for his helpful suggestions.

${ }^{1}$ For example, in 1877 there were only 72,219 hospital beds throughout the German Reich, but this number almost quadrupled in less than forty years, reaching 226,831 by 1911 . This means that for every 10,000 persons, there were roughly 16.5 beds in 1877 and about 41.5 beds in 1911. See Reinhard Spree, Soziale Ungleichheit vor Krankheit und Tod. Zur Sozialgeschichte des Gesundheitsbereichs im Deutschen Kaiserreich, Göttingen, Vandenhoek \& Ruprecht, 1981, p. 101.

\footnotetext{
${ }^{2}$ For a comparative view of the history of health insurance, see E P Hennock, British social reform and German precedents: the case of social insurance 1880-1914, Oxford, Clarendon, 1987; Wolfgang J Mommsen (ed.), The emergence of the welfare state in Britain and Germany 1850-1950, London, Croom Helm, 1981; and Gerhard A Ritter, Der Sozialstaat. Entstehung und Entwicklung im internationalen Vergleich, 2nd ed., Munich, Oldenbourg, 1991.

${ }^{3}$ In the year 1885 , around 10 per cent of the German population were members of a health fund; by 1913, the number had risen to around 25 per cent. See Florian Tennstedt, 'Sozialgeschichte der Sozialversicherung', in Maria Blohmke, et al. (eds), Handbuch der Sozialmedizin. Band 3: Sozialmedizin in der Praxis, Stuttgart, Enke, 1976, pp. 385-492, on p. 386.

${ }^{4}$ On the subject of the self-government of the sickness funds, see Florian Tennstedt, Soziale Selbstverwaltung. Geschichte der Selbstverwaltung in der Krankenversicherung von der Mitte des 19. Jahrhunderts bis zur Gründung der Bundesrepublik Deutschland, Bonn, Verlag der Ortskrankenkassen, [1977].
} 


\section{Sylvelyn Hähner-Rombach}

Since contributions from both sides were compulsory, the new law encountered resistance from workers and employers at first. Some employers avoided the expense by hiring only members of supplementary insurance funds (Freie Hilfskassen)-health funds supported solely by members, with no employer involvement. ${ }^{5}$ Most of these had been founded before the Krankenversicherungsgesetz, and offered members important benefits over the compulsory funds. Entirely financed by members, they could focus on members' needs with no consideration of employer interests. Unlike the compulsory funds, the Freie Hilfskassen frequently offered members a choice between free medical treatment and medication, and sick pay (Krankengeld). In some cases, Freie Hilfskassen were preferred because they were allied with a trade union, ${ }^{6}$ or because employees were disinclined to join any fund that was compulsory.

Some employees rejected both the compulsory and voluntary health funds, seeking to use their income for everyday necessities. This mostly passive resistance to the Krankenversicherungsgesetz did not last long, however, and both employers and employees were soon reconciled to the new reality. In the 1890 s, the Social Democrats tried to win control over the most popular health fund, the local insurance companies (Allgemeine Ortskrankenkassen), by ensuring that the employee representatives in the self-governing body were party members. ${ }^{7}$ This went against the spirit of the law, but was not strictly speaking illegal, and the government could do nothing about it. More often than not, these Social Democrats strove to extend the benefits members received; they did not interfere with the degree or strictness of health fund supervision over members.

This article describes disputes between patients and their health insurance companies over issues of hospitalization; it centres on the concepts of medicalization, professionalization, and disciplining. ${ }^{8}$ The hospital unquestionably played an important role in the process of medicalization. From the middle of the nineteenth century hospital treatment gained more and more acceptance within the working-class, and among the middle classes at the end of the century. ${ }^{9}$ The increasingly positive attitude towards hospital treatment by working-class patients, ended, however, when they were hospitalized against their will, as Barbara Elkeles has shown in her study of working-class autobiographies. ${ }^{10}$ When the health funds acted as agents for disciplining their members-a role inherent in Bismarck's health legislation-members reacted negatively. In this situation, physicians played an ambiguous role in the conflicts between health funds and their members. They were the ones who decided who was ill and who not, who had to go to hospital and who not,

\footnotetext{
${ }^{5}$ See, for example, Tennstedt, op. cit. note 3 above, pp. 389-90, Sylvelyn Hähner-Rombach, Die Betriebskrankenkassen in Baden und Württemberg von der Industrialisierung bis in die Zeit des Nationalsozialismus. Eine Chronik, Tübingen, Silberburg, 2001, p. 68.

${ }^{6}$ See, for example, Ingo Tamm, Arzte und gesetzliche Krankenversicherung in Deutschland und England 1880-1914, Berlin, Verlag für Wissenschaftsund Regionalgeschichte, 1998, p. 123.

${ }^{7}$ See Tennstedt, op. cit., note 3 above, p. 390.

${ }^{8}$ For an overview of research in the social history of medicine, see Martin Dinges, 'Social history of medicine in Germany and France in the late-twentieth
}

century', in Frank Huisman and John Harley Warner (eds), Locating medical history: the stories and their meanings, Baltimore, Johns Hopkins University Press, 2004, pp. 209-36.

${ }^{9}$ See Jens Lachmund, Gunnar Stollberg, Patientenwelten. Krankheit und Medizin vom späten 18. bis zum frühen 20. Jahrhundert im Spiegel von Autobiographien, Opladen, Leske \& Budrich, 1995.

${ }^{10}$ Barbara Elkeles, 'Der Patient und das Krankenhaus', in Alfons Labisch, Reinhard Spree (eds), "Einem jeden Kranken in einem Hospitale sein eigenes Bett". Zur Sozialgeschichte des Allgemeinen Krankenhauses in Deutschland im 19. Jahrhundert, Frankfurt and New York, Campus, 1996, pp. 357-73. 


\section{Hospitalization in Baden, 1893-1914}

and-resulting from this-who would receive sick pay and who not. In addition to the administrator of the health fund, the panel or the hospital physician could side against a sickfund member in a quarrel over whether hospitalization was necessary. Inevitably, some patients were not willing to accept the expertise of the physician: they had their own ideas about which illnesses should be treated in hospital and which not. These lay conceptualizations of disease, ran counter to the physicians' efforts at professionalization. Thus, both the processes of medicalization and professionalization influenced the disciplining of members of health funds. In this context, health legislation became the critical element in disciplining patients. Conflicts between health funds and their members not infrequently ended in the courts, and as a result accelerated the development of social law.

A discussion of the sources will be followed by a short overview of the legislation. Then I will explore the arguments constructed by the health funds in favour of hospitalization and the counter arguments of patients who did not wish to be hospitalized. The relationships between all involved parties will be analysed in the next section, followed by a characterization of the plaintiffs. A discussion of the outcomes of the lawsuits and a comparison with the provisions governing hospitalization in the German Reich will conclude the paper.

\section{The Sources}

The period covered by this investigation begins in 1893 , at a time when health insurance had become generally established in Germany, and ends in 1914. This choice was determined by the sources available: the source material of health insurance companies regarding disputes with patients is rather scanty. ${ }^{11}$ Among the most important records are the case files of the Verwaltungsgericht Karlsruhe, a court of appeal of the Grand Duchy of Baden, containing 991 lawsuits relating to health insurance. There must have been many more lawsuits filed in the courts of first instance, but none have been located.

Each case file typically contains: the plaintiff's claim; the judgment of the court of first instance; the judgment of the court of appeal; occasional statements from expert witnesses; testimonies; and lists of assets. Some plaintiff claims are quite detailed, while others are more generalized. Of course it is essential to bear in mind that these documents were written for the purpose of winning the lawsuit, which would also mean being freed of responsibility for court costs. The court records are complemented by certain insurance periodicals like the Deutsche Krankenkassen-Zeitung, which reported on hearings throughout the country.

The 991 case files contain all the surviving material regarding lawsuits concerning health insurance in this period, including the following types of law suits:

1. A member suing a health fund;

2. A health fund suing a member;

3. A health fund suing another health fund;

\footnotetext{
${ }^{11}$ Not only is there a scarcity of source material relating to health insurance companies' disputes with members, but research in this field is rather rare. The history of patients, at least in respect of health insurance companies in German-speaking countries, is only beginning to emerge. Recently Alfons Labisch and Reinhard Spree stated that in Germany more
}

research is required on the situation of patients in hospital. See the introduction of Alfons Labisch and Reinhard Spree (eds), Krankenhaus-Report 19. Jahrhundert. Krankenhausträger, Krankenhausfinanzierung, Krankenhauspatienten, Frankfurt and New York, Campus, 2001, pp. 13-37, on p. 22. 


\section{Sylvelyn Hähner-Rombach}

4. A health fund suing a regulatory body or public agency;

5. A poverty relief organization suing a health fund;

6. A health fund suing an employer;

7. An employer suing a health fund.

Disputes between health funds and their members concerned not only hospitalization but also numerous other issues such as: membership status in a given voluntary or compulsory health fund, medical and dental expenses and coverage, the amount or duration of sick pay, disability status and benefits, maternity benefits, family allowance, and leaving the sickness fund's district without being permitted to do so.

Out of these 991 files, I selected a very specific group: cases in which patients refused hospital treatment against the instructions of their health funds and/or panel physicians. These include instances where patients left the hospital without a due discharge procedure, or in which they postponed or avoided hospitalization after a panel physician or health fund had clearly ordered it. (These cases are the converse of those where health funds refused to cover the expenses of voluntary hospital stays which they had not authorized.)

In all the cases studied, the member refused hospitalization, was later denied sick pay, sued the health fund for the sick pay, lost the case at the court of first instance, and took the case to the court of appeal. There are 99 cases in this category, or 10 per cent of the records. ${ }^{12}$

\section{Legislation}

In accordance with article 6 of the Krankenversicherungsgesetz, the health insurance company was obliged to grant its members free medical treatment, medication, spectacles and other aids for a period of at least thirteen weeks. ${ }^{13}$ In cases of disability, sick pay amounting to at least half-a-day's wages would be paid from the fourth day of the illness onwards. If financing was ensured, the health funds could offer extended benefits, or extend coverage to include family members. However, the health funds were not required to pay benefits for illnesses resulting from fighting, drunkenness or sexual irregularity.

Article 7 of the same law stated that, instead of medical treatment and sick pay, the sickness fund could choose to grant free hospital treatment. ${ }^{14}$ In the case of unmarried members or members not living at home, the health fund was free to choose inpatient treatment, without consulting the patient. In the case of married members or members living at home, however, patient consent for hospitalization was required. For such members, hospitalization was compulsory in cases where the illness was too serious to be treated properly by the family; the illness was infectious; the patient failed to follow health fund

\footnotetext{
${ }^{12}$ In 1897 , on average 383,581 people were members of a compulsory health insurance in the Duchy of Baden, with altogether 130,060 cases of illness. (Unfortunately no information about the numbers hospitalized could be found.) See Großherzogliches Statistisches Landesamt (ed.), Statistische Mittheilungen über das Großherzogthum Baden, XV. vol. 25, Karlsruhe, 1898, pp. 220, 221. By comparison with these figures, 991 lawsuits between 1893 and 1914 is low. But, as already noted, sources are scanty and these lawsuits not
}

\footnotetext{
only add to the records but also provide another source for research.

${ }^{13}$ In 1903 the period was extended to twenty-six weeks.

${ }^{14}$ The health funds were not obliged by law to pay for hospital care; they could use their discretion. See, for example, Alfons Labisch, 'Stadt und Krankenhaus. Das Allgemeine Krankenhaus in der kommunalen Sozial- und Gesundheitspolitik des 19. Jahrhunderts', in Labisch and Spree (eds), op. cit., note 10 above, pp. 253-96, on p. 267.
} 


\section{Hospitalization in Baden, 1893-1914}

regulations; or the member's condition or behaviour "required continuous observation" (as in cases of suspected malingering).

\section{The Health Funds' Case}

There were several reasons why the health funds would send a patient to hospital: first because the patient was suffering from an illness which made hospitalization necessary; second, to shorten the recovery period and reduce expenses; third, to have better control over patients living in the peripheral areas where there was no supervision; fourth, to punish the patient for disregarding health fund regulations (not maintaining bed rest, etc.); and fifth, to expose malingering. ${ }^{15}$

Besides the medical reasons for hospitalization there were thus also non-medical issues, which were sometimes clearly admitted: "After the health fund's experiences with patients living outside the district, the fund will no longer abstain from using hospitalization."16 Above all, health funds realized important savings by using hospitalization. Unlike today, hospital care in this period was far less costly than sickness benefits, partly because hospital physicians' wages were included in hospital expenses, so that health funds were not required to pay for their services. ${ }^{17}$

Of the 99 cases studied, 67 (67.7 per cent) patients entirely disregarded the health fund's hospitalization instructions, 5 (5 per cent) were hospitalized, but in a hospital other than the one specified by the fund, 27 (27.3 per cent) arrived at hospital later than required or left without authorization. Of these 67 case files, 38 provide further detail about the arguments presented by the health funds. These are summarized in Table 1.

In summary, the main arguments presented by health funds centred around contravention of the regulations, malingering, and the need for constant observation. Supervisors are mentioned explicitly in only eight of the 38 case files, but supervisor visits are alluded to indirectly in several other files. ${ }^{18}$

Arguments related to medical considerations, such as "nursing at home is not guaranteed" or "infectious disease" were rarely mentioned, never emphasized, and always

\footnotetext{
${ }^{15}$ With the introduction of health insurance, the fear-or rather suspicion—grew that people would stay away from work on the pretext of being ill. Consequently, the health funds often set up control mechanisms. There is little research on malingering in relation to health insurance. There is a thesis by Anna-Maria Schuster on 'Simulation von Krankheiten in der zweiten Hälfte des 19. Jahrhunderts unter besonderer Berücksichtigung der Sozialversicherungsgesetzgebung der späten 1880er Jahre', University of Stuttgart, 2001. For other examples, see Ingrid von Stumm, Gesundheit, Arbeit und Geschlecht im Kaiserreich am Beispiel der Krankenstatistik der Leipziger Ortskrankenkasse 1887-1905,

Frankfurt/Main, Lang, 1995, pp. 41-3.

${ }^{16}$ Generallandesarchiv (hereafter GLA) Karlsruhe, Bestand 239, Nr. 7146.

${ }^{17}$ Between 1896 and 1913, the sickness funds in Baden paid out between 1.82 and 5.81 marks per member per year for hospital care and between 5.00 and
}

15.68 marks per member per year for sick pay. See Hähner-Rombach, op. cit., note 5 above, pp. 108-9. As the sickness funds did not have to pay for medical care in hospital (at least until 1913), they were more interested in inpatient treatment than in ambulant treatment. See Bernd Nierlich, Krankenhausärzte und Krankenhauspatienten. Ihre psychosoziale und sozialrechtliche Darstellung im Deutschen Ärteblatt und in der Münchener Medizinischen Wochenschrift im Zeitraum von 1885-1945. Ein inhaltsanalytischer Vergleich, Herzogenrath, Murken-Altrogge, 1991, p. 144. For the financing of the hospitals in this period, see Gunnar Stollberg, Ingo Tamm, Die Binnendifferenzierung in deutschen Krankenhäusern bis zum Ersten Weltkrieg, Stuttgart, Franz Steiner, 2001; Labisch, and Spree (eds), op. cit., note 11 above.

${ }^{18}$ Supervisors were used elsewhere. The big local insurance company in Leipzig with 103,492 members in 1896 , employed 184 voluntary supervisors (called visitors), who made 79,332 visits in that year. 


\section{Sylvelyn Hähner-Rombach}

Table 1:

Health funds' arguments for hospitalization other than medical reasons

\begin{tabular}{lcc}
\hline & Numbers & Percentage \\
\hline $\begin{array}{l}\text { Total number of sick members' who } \\
\text { disregarded health fund regulations }\end{array}$ & 21 & 32.3 \\
(a) Working & 7 & 10.8 \\
(b) Drinking alcohol or going to the pub & 4 & 6.2 \\
(c) Not at home/in bed when supervisor/panel & 2 & 3.1 \\
$\quad$ physician visited & & \\
(d) Did not follow health fund instructions & 6 & 9.2 \\
(e) Did not follow orders to stay at home & 2 & 3.1 \\
Health fund's evaluation of cases & & \\
Suspicion of malingering & 15 & 23 \\
Constant observation required* & 11 & 16.9 \\
Infectious disease & 5 & 7.7 \\
Nursing at home not guaranteed & 3 & 4.6 \\
Efficiency control over the patient & 3 & 4.6 \\
Exaggeration of illness & 2 & 3.1 \\
Being single & 2 & 3.1 \\
Poor domestic conditions & 2 & 3.1 \\
Patient not interested in full recovery & 1 & 1.5 \\
\end{tabular}

*Observation not in a medical sense, but in a sense of discipline.

Note: multiple mentions were possible.

accompanied by other, non-medical, justifications. Generally, these were not produced in the first lawsuit, and only emerged before the court of appeal. ${ }^{19}$ Altogether, everything points to the fact that hospitalization could be used, at least partially, as a way of disciplining health fund members. In some cases, the health funds themselves put it clearly enough:

The whole behaviour of the plaintiff forced ... our administration to the conviction that he is malingering. ... It would lead to untenable conditions if members avoid the legitimate instructions of the health fund with lies and untrue statements. The terribly negative balance sheets of almost all large health funds in the last years make it the duty of all administrations to monitor closely people such as the plaintiff, and to implement strictly what little coercive means the legislation allows health funds in handling such people. ${ }^{20}$

There is no evidence that the local insurance companies acted any differently from other health funds, such as the company health insurance (Betriebskrankenkasse) established by specific companies for their own employees: of the 99 plaintiffs, 20 (20.4 per cent) were members of a company health insurance. From 1886 to 1911 , an

Another thirteen professional supervisors made 146,899 visits. See Alfons Labisch, Homo Hygienicus. Gesundheit und Medizin in der Neuzeit, Frankfurt and New York, Campus, 1992, p. 182.

\footnotetext{
${ }^{19}$ This led sometimes to the sickness fund losing the lawsuit because it changed the reason for hospitalization.

${ }^{20}$ GLA Karlsruhe, Bestand 239, Nr. 6694.
} 
average of 30.5 per cent of Baden health fund members belonged to a corporate company health insurance. ${ }^{21}$ So members of a company health insurance fund were underrepresented in these lawsuits.

In conclusion, health funds used hospitalization to protect at least two important interests: reduction in costs and the disciplining of members. Non-compliance resulted in withdrawal of sick pay benefits. Patients were far from willing to be hospitalized when there was no urgent need. The sources include the cases of almost 100 patients who lost sick pay benefits because they avoided hospitalization. Their reasons are outlined in the next section.

\section{The Patients' Case}

One of the main reasons for patients not going to hospital was probably money. Sick pay was normally half a day's wages if the patient stayed at home, but far less during hospitalization. ${ }^{22}$ In general, all women and unmarried men forfeited their sick pay once they were hospitalized, and married men received only half of the normal sick pay. The justification for this was that the man was the breadwinner of the family, and the wife's income was only a contribution that was expendable when she had to go to hospital.

Another reason for patients refusing hospitalization was the low quality of the hospitals themselves and the relatively poor prospects of successful treatment. ${ }^{23}$ The quality of hospitals - staff, facilities and equipment-was very often far from satisfactory at this time,${ }^{24}$ and was criticized by doctors themselves. ${ }^{25}$ Despite progress in surgery and hygiene, and a decrease in mortality rates, many hospitalized patients were not cured, and many people avoided hospitals - even when ordered there by their health funds. As

\footnotetext{
${ }^{21}$ These numbers declined over time. In 1886, 49 persons out of 100 were members of a company health insurance fund, in 1914 only 26.5. See HähnerRombach, op. cit., note 5 above, pp. 98-9.

${ }^{22}$ For TB patients who were sent to a sanatorium for three months the financial problems were even worse, and resulted sometimes in the patients leaving the sanatorium without authorization, see Sylvelyn Hähner-Rombach, Sozialgeschichte der Tuberkulose. Vom Kaiserreich bis zum Ende des Zweiten Weltkriegs unter besonderer Berücksichtigung Württembergs, Stuttgart, Franz Steiner, 2000, pp. 327-8.

${ }^{23}$ Elkeles writes that, despite the progress made in hospital therapy and hygiene in the nineteenth century, at the beginning of the twentieth century people still tried to avoid hospitalization, mainly because of the low quality of nursing care, the bad state of the buildings and poor hygiene. Bureaucracy and rigorous house rules further aggravated the situation. See Barbara Elkeles, 'Das Krankenhaus um die Wende vom 19. zum 20. Jahrhundert aus der Sicht seiner Patienten', Historia Hospitalum', 1986/88, no. 17, pp. 89-105.
}

\author{
${ }^{24}$ See, for example, the boycott of the Charite \\ in Berlin in 1893, in Reinhard Freiberg, 'Der \\ Charité-Boykott im Jahre 1893. Eine \\ medizinhistorische Studie über Auswirkungen der \\ Arbeitersozialreformen der 80er und 90er Jahre des 19. \\ Jahrhunderts', PhD thesis, Humboldt-Universität \\ Berlin [1997], idem, 'Der Charité-Boykott im Jahre \\ 1893', in Peter Schneck (ed.), Medizin in Berlin an der \\ Wende vom 19. zum 20. Jahrhundert, Husum, \\ Matthiesen, 1999, pp. 141-50. In this case, the sickness \\ funds in Berlin worked together with the Social \\ Democrats in favour of their members against the \\ hospital. The conditions in hospitals did not improve \\ generally, however. The following was written as \\ late as 1913: "Beispielsweise ist es schon \\ vorgekommen, daß die Einrichtungen des \\ Krankenhauses so unzulänglich waren, oder daß der \\ Aufenthalt im Krankenhause als so schädlich für \\ den Kranken erachtet werden mußte, daß die Gerichte \\ in dem Verlassen des Krankenhauses eine \\ unbefugte Handlung nicht erblicken konnten." \\ Deutsche Krankenkassen-Zeitung, 1913, 13: 17. \\ ${ }^{25}$ See Elkeles, op. cit., note 10 above, p. 362.
}




\section{Sylvelyn Hähner-Rombach}

mentioned above, plaintiffs' claims varied widely in the depth and detail of their arguments. From the statements put forward, we can assume that plaintiffs were generally aware of legal precedents and ideologies, and knew which arguments were likely to persuade the court.

Married men, for example, often referred to the Health Insurance Act, asserting that, because of their marital status, they were not obliged to go to hospital. They argued for the right to stay at home, even if it was outside the town where they worked and where the sickness fund was based. After a number of lawsuits focused on these claims, the Badische Verwaltungsgericht Karlsruhe introduced a rule in 1908 that married members were indeed allowed to choose home treatment even when they lived out of town. The health fund had the right to insist on hospitalization only if the journey home seemed dangerous or detrimental to the member's health. ${ }^{26}$ In spite of this, the health funds won some cases against married members when the reason for hospitalization was suspected malingering. The argument of the court was then that these patients needed to be under observation.

Some married men claimed that their wives were too ill or weak to be left at home alone. A bricklayer, whose wife was in advanced pregnancy, pointed out: "On the one hand, I was urgently needed at home, and on the other hand my hospitalization could frighten my wife." 27 Comparatively few married men used the plea that they could not afford the financial loss that a stay in hospital represented: "My refusal of hospitalization was all the more legitimate as my family would have had to live on half the sick pay, which is not enough for their maintenance." ${ }^{28}$ In fact, this argument carried little persuasive power in the courts; and the court rulings never referred to a family's financial situation. This may explain why plaintiffs so rarely resorted to such claims. Unmarried men living with their families (normally their parents), also maintained that their families could take care of them, and that they did not need go to hospital. However, this argument was not enough in and of itself; additional reasons were required to persuade the court.

Unmarried members also suffered financial losses from hospitalization, but they had recourse to fewer arguments to avoid the hospital. As a female factory worker complained in 1897: "I particularly appealed to them to accept my refusal to go to hospital again, because I have my own household and there is nobody who would take care of it while I am in hospital. How would I pay my rent? I would lose my boarder and my few furnishings. Hospitalization would have meant losing all my personal belongings, which cannot be the purpose of the law." 29 The law may not have intended this, but it was not persuaded by such arguments, which may be one reason why unmarried workers sometimes asserted that they were not specifically instructed to go to hospital by the panel physician, or that their family doctor was opposed to hospitalization. Some simply denied the need for hospitalization by claiming to be nearly well: "I did not know that I was obliged to go to hospital for the last two days of my illness." ${ }^{30}$ Others attempted to buttress their credibility: "Dr Katz's assumption that I am malingering is not believable. If it were true I would not have refused hospitalization.",31 9: 216 .

${ }^{26}$ See Deutsche Krankenkassen-Zeitung, 1909,

${ }^{27}$ GLA Karlsruhe, Bestand 239, Nr. 7202.

${ }^{28}$ GLA Karlsruhe, Bestand 239, Nr. 7202.
${ }^{29}$ GLA Karlsruhe, Bestand 239, Nr. 6671.
${ }^{30}$ GLA Karlsruhe, Bestand 239, Nr. 7366.
${ }^{31}$ GLA Karlsruhe, Bestand 239, Nr. 6994. 


\section{Hospitalization in Baden, 1893-1914}

In most cases, the plaintiff referred to a fruitless previous hospitalization as one of the reasons, or even the only reason, for avoiding the health fund's orders. Some plaintiffs went into considerable detail in describing previous bad hospital stays, like Rosa Flidt in 1908, who was ordered to return to the very same hospital where some months before, "I was obliged to do hard work for fourteen days despite being ill. Every day I had to clean the floors, and carry the heavy coffeepots from the kitchen. I did not have a bed to sleep in at night, only an old mattress on the floor. This is the reason why I did not follow the panel physician's second hospitalization order.",32

Even worse were the experiences of the maid, Christiane Treffinger, also in 1908. She came to hospital suffering from a skin disease which her mistress had refused to take care of. She had the misfortune to be assigned to the scabies ward,

It was very embarrassing to be treated like a scabies patient, which, as the family doctor can confirm, was entirely inappropriate for me. If I had been treated right I would not have lost my job. Furthermore, I should say that I had to sleep on the corridor because of lack of room. My bed stood directly beside the cells of the insane, where I could not sleep-which was very harmful as I am nervous. In this period there were three insane persons. On November $28^{\text {th }} 1907$ a woman in a straitjacket arrived. Because of the lack of room, another patient was placed beside her. In the middle of the night the insane woman had an attack of acute mania and tried to strangle the other woman. She would have succeeded if another patient had not opened the door. The near-strangled woman came out, entirely covered in blood. This is the state of affairs in this hospital. ${ }^{33}$

In addition to all this, Christiane Treffinger never received any treatment in the hospital, and left without authorization, which was why the health fund refused to award her sick pay.

This case demonstrates several points. First, that the hospital had undertaken the responsibility of caring for the sick "labouring poor" when the employer refused to do so; and second, that becoming ill could also mean losing employment. Third, certain illnesses such as scabies still stigmatized the patient (it was not by chance that the scabies and insanity wards were adjacent, and that neither had enough resources). And fourth, that the conditions in the hospital were-at least in some cases-far from satisfactory.

In addition to descriptions of such abysmal conditions, there were various criticisms of the nurses and physicians, which will be discussed later. Some plaintiffs claimed that the hospital had adverse effects in and of itself: "I could not sleep in the hospital. The coughs and groans of the other patients were so disturbing and irritating that I could not get any sleep." "34 Others criticized the hospital's distinctive smell, like the female patient who wrote: "I could not follow the rehospitalization order because the last stay in hospital aggravated my lung disease. Witness, nurse Sophie, who can confirm that she found me mostly sitting up in bed, as the smell of the Phenol and Morphine made me struggle for breath so that several times during the night $I$ had to sit at the open window because of a terrible cough.... These strong smells and the sight of other patients vomiting, took away any appetite I may have had, so that all I could do was to sustain myself with a bit of wine." 35 Ward-mates' illnesses were also mentioned several times, as in the evidence of the school

${ }^{32}$ GLA Karlsruhe, Bestand 239. Nr. 7351.

${ }^{33}$ GLA Karlsruhe, Bestand 239, Nr. 7269.
${ }^{34}$ GLA Karlsruhe, Bestand 239, Nr. 6577.
${ }^{35}$ GLA Karlsruhe, Bestand 239, Nr. 6671. 


\section{Sylvelyn Hähner-Rombach}

caretaker Scholl, who "feared the aggravation of the condition" 36 of his son Ambros after witnessing sights such as a pulmonary haemorrhage in an adjacent bed.

It is striking that some tuberculosis patients-who constitute a full 17 per cent of the whole group-denied the danger of infection from their illness. Here is a typical statement, "The notion that an affection of tuberculosis is infectious in the sense of paragraph 7 of the Health Insurance Act must be denied. There are thousands of tuberculosis patients who live with their families without infecting them." 37 Some of them maintained that a stay in hospital would be useless, as their tuberculosis was chronic; others declared such a stay would be harmful; and a third group demanded to stay in a sanatorium instead of a hospital. In any case, these patients consistently rejected the findings of bacteriology. ${ }^{38}$

Table 2 summarizes the arguments or pleas plaintiffs used to defend their refusal to be hospitalized, despite the health fund's orders. Since some defendants produced several arguments, the total sum of these is almost double that of the 99 cases studied (172, plus 7 cases with no explicit argument). It is impossible to determine how precisely they describe patients' real reasons for refusing (further) hospitalization; nevertheless, it is safe to assume that patients believed these to be the most effective arguments they could use in their defence before the court. Based on this assumption, we can conclude that in this period, the best and most convincing reasons for avoiding hospitalization were access to better care at home, marital status, and early discharge from the hospital.

\section{Patients, Physicians, and Health Fund Representatives}

These case studies do not directly describe the relationship between patients and physicians, ${ }^{39}$ but certain remarks can shed light upon this matter. To begin with, we know that there were several distinct classes of physicians: panel physicians, family doctors, medical specialists, and hospital physicians.

Patients sometimes tried to play off the physicians against each other or against the health funds; for example, by claiming that their family doctor was opposed to hospitalization or that the panel physician had not referred them to the hospital. In fact, most of the comments about physicians (appearing in 39 of the 99 cases) claimed some degree of disagreement between hospital physician, panel physician and family doctor. Typically, patients claimed that their family doctor had stated that hospitalization was not necessary, emphasizing that he knew them much better than the panel physician or hospital physician. In a few cases,

\footnotetext{
${ }^{36}$ GLA Karlsruhe, Bestand 239, Nr. 6453.

${ }^{37}$ GLA Karlsruhe, Bestand 239, Nr. 6508.

${ }^{38}$ Given that there were physicians who needed some time to accept bacteriological findings regarding $\mathrm{TB}$, it is not surprising that acceptance among patients took longer. For the debates among British physicians, see Michael Worboys, Spreading germs: disease theories and medical practice in Britain, 1865-1900, Cambridge University Press, 2000, pp. 193-233.

${ }^{39}$ For the relationship in general between physicians and patients from the end of the eighteenth century to the early twentieth century, see, for example,
}

Claudia Huerkamp, ‘Ärzte und Patienten. Zum strukturellen Wandel der Arzt-Patient-Beziehung vom ausgehenden 18. bis zum frühen 20. Jahrhundert', in Alfons Labisch and Reinhard Spree (eds), Medizinische Deutungsmacht im sozialen Wandel des 19. und frühen 20. Jahrhunderts, Bonn, Psychiatrie-Verlag, 1989, pp. 57-73. For the relationship after the introduction of the health insurance, see, for example, Claudia Huerkamp, Der Aufstieg der Ärzte im 19. Jahrhundert. Vom gelehrten Stand zum professionellen

Experten: Das Beispiel Preußens, Göttingen, Vandenhoek \& Ruprecht, 1985, pp. 216-24. 
Table 2:

Patients' arguments for avoiding hospitalization or for early discharge

\begin{tabular}{|c|c|c|}
\hline Arguments & Number & Percentage* \\
\hline Access for better care at home & 42 & 24.4 \\
\hline Married & 20 & 11.6 \\
\hline Discharged by hospital physician & 11 & 6.4 \\
\hline Unacceptable hospital conditions & 8 & 4.6 \\
\hline Hospitalization questionable as therapeutic technique & 8 & 4.6 \\
\hline Previous experience of ineffectual hospitalization & 6 & 3.5 \\
\hline Denial of malingering or breaking health fund regulations & 6 & 3.5 \\
\hline Hospitalization seen as punishment/expulsion attempt & 6 & 3.5 \\
\hline Hospitalization not warranted & 5 & 2.9 \\
\hline Family doctor opposed to hospitalization & 5 & 2.9 \\
\hline Breadwinner & 5 & 2.9 \\
\hline Needed at home to care for sick wife & 4 & 2.3 \\
\hline Harm caused by exposure to sick roommates & 4 & 2.3 \\
\hline Hospitalization referral given too late & 4 & 2.3 \\
\hline Problematic physicians during previous hospitalization & 4 & 2.3 \\
\hline Family must receive the sick pay in full & 4 & 2.3 \\
\hline Homesickness & 3 & 1.7 \\
\hline Adverse effect of hospitalization & 3 & 1.7 \\
\hline Ineffectual treatment at hospital & 3 & 1.7 \\
\hline Requirement for different hospital & 3 & 1.7 \\
\hline Change in diagnosis during hospitalization & 3 & 1.7 \\
\hline Requirement for a sanatorium, not a hospital & 3 & 1.7 \\
\hline Denial of the infectiousness of the disease & 2 & 1.2 \\
\hline Inability to undertake the journey/transport problems & 2 & 1.2 \\
\hline Prolonged hospitalization exacerbates lung disease & 2 & 1.2 \\
\hline Disagreement with the health fund's regulations ${ }^{\dagger}$ & 2 & 1.2 \\
\hline Referral not based on a medical examination & 1 & 0.6 \\
\hline Inability to work had already been approved & 1 & 0.6 \\
\hline Denial of need for observation & 1 & 0.6 \\
\hline Lack of hospital facilities & 1 & 0.6 \\
\hline No explicit pleas & 7 & 7.1 of the 99 cases \\
\hline
\end{tabular}

*The percentage relates to the total of 172 arguments or pleas, not to the number of cases.

${ }^{\dagger}$ Therefore the patient did not know that he/she was obliged to follow the hospitalization order

patients claimed that a physician had recommended specialty treatments that were not available at the hospital in question.

In several cases, patients changed their physician when they did not agree with his opinion, a common enough phenomenon from the early years of health insurance. In some cases, patients even accused physicians of lying; for example, hospital physicians who refused to grant discharges, or panel physicians who issued negative reports of the patient's domestic conditions: "I strongly contest that the care and food supply at my home 


\section{Sylvelyn Hähner-Rombach}

were poor. Dr Buchmüller cannot say that, since he was never responsible for my diet." Typically, complaints about hospital physicians claimed that they did not take care of the patients-failing to visit them for days at a time, or declaring them fit for work without so much as a medical examination. Others complained of physicians' arrogance. In one case, the panel physician asked a tuberculosis patient: “ 'Are you able to work?' I answered no, he said, 'Who will believe that? ... we know you by now', he makes me out to be a bad person. I told him therefore, 'Leave me alone I am anyway sick enough', whereupon he threatened to discharge me and showed me the door. I left the consulting room. When I came to the health fund in the afternoon, I heard that he had referred me to the hospital." ${ }^{41}$ In this example, the patient implied that the panel physician was using hospitalization as a punishment for disagreeing with him.

In another case, a sepsis patient claimed that when he had been unable to request a home visit because the panel physician had only been available a day later: "His behaviour was extraordinarily rude, through which I lost that all-important confidence in him." 42 Some parents claimed that they withdrew their children due to physicians' unsatisfactory medical treatment. In one case, a young maid working in a village visited the panel physician but described only one of her ailments, because, according to her mother, she was "afraid it would take up too much of his time to describe the other disease as well." ${ }^{43}$ However, this is the only example in which the patient expressed undue respect and shyness before the academic physician. The majority of patients seemed quite aware that they had at least some rights: "He [the patient, S. H.] must put up with hospital treatment but not with such behaviour from the physician." 44 Some patients expressed deep mistrust, particularly of physicians recommended by the health fund. One member of a company health insurance fund questioned the opinion of a physician who, according to her, "was related to the owner of the company" and whose recommendation contradicted the instructions of her family doctor, "whose opinion was not asked". 45

In some cases, the court consulted medical experts, who might support either the patients or the health funds. In other cases, the court accepted family doctors' opinions, which sometimes contradicted patients' claims. Altogether, physicians' statements supported patients' claims only in a minority of the cases. More often than not, physicians statements' supported the health funds; and physicians, as well as health fund representatives, commonly ordered hospitalization.

It is safe to assume that during the study period, physician-patient relations were characterized by differences in power, social prestige, education and culture. It was the physician who decided who was ill and who not; how the patient must be treated (inpatient/ outpatient care, type of medication, etc.); and whether or not the patient was capable of working. Yet, despite the fact that the physician had almost full authority regarding management of the illness, his role-particularly if he was a panel physician-was also quite ambiguous. On the one hand, he was responsible for the patient's recovery; on the other, he had to keep in mind the interests of the health funds. The case studies suggest that health funds' were suspicious of physicians: they too often certified patients as ill, they

${ }^{40}$ GLA Karlsruhe, Bestand 239, Nr. 6452.

${ }^{41}$ GLA Karlsruhe, Bestand 239, Nr. 6689.

${ }^{42}$ GLA Karlsruhe, Bestand 239, Nr. 6678.
${ }^{43}$ GLA Karlsruhe, Bestand 239, Nr. 6673.

${ }^{44}$ GLA Karlsruhe, Bestand 239, Nr. 6745.

${ }^{45}$ GLA Karlsruhe, Bestand 239, Nr. 6895. 


\section{Hospitalization in Baden, 1893-1914}

prescribed too many costly medications, etc. Panel physicians had good reason to dislike their dependence upon the health funds, but this type of work was an important source of income. ${ }^{46}$

In general, health fund representatives and members had conflicting positions and interests. From the inception of health insurance there existed a fear of malingering and a deep mistrust of any member claiming an illness. This mistrust never abated, even when statistics showed that, although the number of cases of illness increased, illness levels among health fund members were lower than expected. These anxieties led to the early establishment of the position of supervisor: an administrator who represented one or several health funds vis-à-vis the members. Some company health insurance funds tried to reduce costs by giving the responsibility to fund members, on a rotating basis. However, this system was shortlived, as it caused difficulties among the insured, and corporate funds were forced to hire neutral persons for this position. Supervisors were responsible for determining the veracity of the member's illness by visiting their homes, and even conducting amateur investigations regarding their claims. ${ }^{47}$ Naturally, the relationship between supervisors and fund members was far from friendly.

Likewise, communication between members and health fund representatives was also problematic. One patient's claim states: "When it turned out that my disease would last longer, the health fund tried to get rid of me ... First they claimed that I was not ill at all, pointing out the rosiness of my cheeks. Then they said that the physician with whom I am quite satisfied, was unacceptable, and that I must consult a different physician. Each time I came to collect my sick pay, they yelled at me, saying that I was acting as if I could continue collecting sick pay for three years, and so on." 48 In another case the member declared that the board of the health fund had told him, "that they do not owe sick pay to a social democrat who led a soldier to a social democratic pub." 49

In general, relations were not as bad as these examples suggest, but the conflict of interest remained. Typically, conflicts arose not only because members refused the hospitalization referral of the health fund representatives, but also from the suspicion of malingering, and the health fund's attempts to control its members. For instance, one fund quoted the observations of its supervisor in supporting the claim that hospitalization was required: "Z. suffers from an infectious venereal disease; his father's family includes five persons living in three rooms and one attic ... The medical treatment of such a disease in a poor family with such limited living space seems to be inappropriate for moral reasons." 50 Patients sometimes disagreed with administrators regarding the choice of hospital: "My daughter told the administrator of the health fund, Mr Eckerlin, that she would like to go to

\footnotetext{
${ }^{46}$ See, for example, Tamm, op. cit., note 6 above, ch. 3; Hedwig Herold-Schmidt, 'Ärztliche Interessenvertretung im Kaiserreich 1871-1914', in Robert Jütte (ed.), Geschichte der deutschen Arzteschaft. Organisierte Berufs- und Gesundheitspolitik im 19 und 20. Jahrhundert, Köln, Deutscher Ärzte-Verlag, 1997, pp. 43-95, on pp. 82-95.

${ }^{47}$ An extreme example of the observation of ill members is given in Marlene Ellerkamp,
}



Industriearbeit, Krankheit und Geschlecht. $\mathrm{Zu}$ den sozialen Kosten der Industrialiserung: Bremer Textilarbeiterinnen 1870-1914, Göttingen, Vandenhoek \& Ruprecht, 1991, pp. 219-220.

${ }^{48}$ GLA Karlsruhe, Bestand 239, Nr. 6895.

${ }^{49}$ GLA Karlsruhe, Bestand 239, Nr. 6477.

${ }^{50}$ GLA Karlsruhe, Bestand 239, Nr. 6658. 


\section{Sylvelyn Hähner-Rombach}

the hospital in Riehen. But Mr Eckerlin told her that this hospital is too expensive, and that she must go to Lörrach." 51

In other cases, the employer "cooperated" with the health fund in a way that adversely affected the patient's interests. In one case, an employer reported to the fund that one of his female workers had violated the regulations by doing housework during her sick leave. ${ }^{52}$ Patients often argued that they had never received the health fund's regulations, and therefore could not know that they were obliged to follow the hospitalization orders. In such cases, health funds never offered counter-arguments; from which we can assume that the terms were not normally given to each member. Nevertheless, members' claims of ignorance about the regulations were not normally upheld by the court.

Some married men requested permission to recover at home, where their wives could take care of them, but all these requests were turned down, no doubt contributing to the hard feelings between members and health fund representatives. One patient went to his fund after having been told by his colleagues that, as a married man, he did not need go to hospital:

I explained to the official there that my wife, who is weak in any case, will soon give birth, and that there is nobody at home to assist her other than an old mother-in-law and a two-year-old child. I wanted to make it very clear that my presence at home was essential. I told him at the same time that my hospitalization could have a very harmful effect on my wife, by causing her a great deal of worry. Given all this, I asked him for a referral for sick leave at home, but he refused. I had never seen the health fund's regulations, so I considered the official's treatment a kind of harassment. For that reason, I told him that I would leave without any referral. ${ }^{53}$

Stories such as this one did little to improve the relationship between members and their health funds, particularly as reports of such negative experiences spread rapidly through word-of-mouth.

In summary, we can say that in principle, the patient-physician relationship varied widely in the cases studied. The physician might support the patient in his/her fight against the hospitalization ordered by the health fund, but in other instances he might side with the fund. On the other hand, in cases presented to the courts, the relationship between the patient and his/her health fund was clearly contentious, characterized by sharply opposing interests. Nevertheless, the patients in these case files had enough self-confidence to defend themselves against the health fund's decision to deny them sick pay.

\section{Who Were the Plaintiffs?}

Of the 99 cases studied, 75 (75.75 per cent) of the defendants were male, and 24 (24.25 per cent) were female members of health funds. As previously mentioned, around 20.2 per cent of the plaintiffs were members of a company health insurance fund. During this period, these funds (Betriebskrankenkassen) and the local insurance companies (Allgemeine Ortskrankenkassen) were the largest and most popular health

${ }^{51}$ GLA Karlsruhe, Bestand 239, Nr. 6871.

${ }^{53}$ GLA Karlsruhe, Bestand 239, Nr. 7202.

${ }^{52}$ GLA Karlsruhe, Bestand 239, Nr. 6934. 


\section{Hospitalization in Baden, 1893-1914}

providers. When health insurance became compulsory, company health insurance funds were by far the most popular in Baden, but by 1892 the local insurance companies had surpassed them in size. On average, company health insurance funds accounted for about 30 per cent of all insured persons. ${ }^{54}$ Women accounted for 36.9 per cent of company funds in 1886 and 28.9 per cent in 1913; and 21.4 per cent of the local insurance companies in 1886 and 39.8 per cent in 1913. From this, we can conclude that women and members of company health insurance funds are under-represented in the lawsuits of the court of appeal.

In 88 of the 99 cases, the health fund members themselves were the plaintiffs; but the suits could also be submitted by the member's father ( 7 cases), widow or successors ( 3 cases), or husband (1 case). Nine patients sued in forma pauperis, which meant they did not have to pay the legal costs; sixteen had a lawyer, and four were represented by trade unionists or Arbeitersekretäre. ${ }^{55}$ Of those whose family status can be determined, seven were single, twenty-five married, and thirty-four lived with their families. Half of the plaintiffs (55.5 per cent) lived in the countryside. Of the male plaintiffs, forty-three were craftsmen (bricklayers, joiners, mechanics, etc.); ten were general workers or day labourers; seven were clerks; and the remainder did not specify their occupations. Of the female plaintiffs, nine did not specify occupations, five were working women, seven were domestic servants, two were saleswomen and one was a clerk. Plaintiffs' ages ranged between sixteen and sixty-nine years, with the majority aged twenty-five to fifty.

The average plaintiff was neither well-to-do nor educated. In twenty of the cases, there are references to assistance obtained in filing the lawsuit, including services from Arbeitersekretäre, or lawyers. In three additional cases, we can assume that help was obtained because the handwriting in the statement of claim differs from the plaintiff's (one woman even signed with three crosses); and in five other cases the statement of claim is written in a refined style, hinting that help was obtained from a more educated person. Since these cases were presented to the court of appeal, we know that all the plaintiffs had already lost a case, and were taking the risk of losing again and incurring additional financial losses. This may indicate a firm belief that the health funds had acted unjustly towards them.

Since the health funds used medical considerations as a central argument for hospitalization, a short look at the types of illness is instructive. ${ }^{56}$ The most striking observation that emerges from Table 3 is that in a full 30 per cent of cases the health insurance funds did not feel obliged to give a specific diagnosis; indicating that medical reasons were not the primary or only grounds for hospitalization. As noted above, numerous patients were diagnosed with tuberculosis - an illness that could be diagnosed quite well at this time-but many requested sanatorium rather than hospital treatment, claiming that their condition was chronic. Most of the other diagnoses-including accidents at work which were generally rather minor-did not necessarily require hospitalization. Altogether,

\footnotetext{
${ }^{54}$ They started with 49 per cent in 1886 and had 26.5 per cent in 1914. See Hähner-Rombach, op. cit., note 5 above, pp. 98-9.

${ }^{55}$ Arbeitersekretäre could be representatives of the trade unions or of the Protestant church. Their task
} was to support workmen in different fields, offering,
among other things, legal assistance.
56 The problem of retrospective diagnosis will not
be discussed here. 


\section{Sylvelyn Hähner-Rombach}

Table 3:

Types of illnesses suffered by plaintiffs

\begin{tabular}{lcc}
\hline Illness & Quantity & Percentage \\
\hline Tuberculosis (including 1 unspecific lung disease) & 17 & 17.2 \\
Accident at work & 13 & 13.1 \\
Bone disease (e.g. arthritis, etc.) & 7 & 7.1 \\
Rheumatism & 6 & 6.1 \\
Internal disease (stomach, heart) & 6 & 6.1 \\
Nervous disease & 4 & 4.0 \\
Furuncle & 3 & 3.0 \\
Suspicion of typhoid & 2 & 2.0 \\
Suspicion of poisoning & 2 & 2.0 \\
Venereal disease & 2 & 2.0 \\
Illness during pregnancy & 1 & 1.0 \\
Appendicitis & 1 & 1.0 \\
Angina & 1 & 1.0 \\
Haemorrhoids & 1 & 1.0 \\
Scabies & 1 & 1.0 \\
Indisposition & 1 & 1.0 \\
Operation & 1 & 1.0 \\
No specific diagnosis & 30 & 30.3 \\
\hline
\end{tabular}

analysis of the types of illness cited seems to confirm that there was room for doubt regarding the health funds' claims that hospitalization was necessary.

By submitting the case to the court of appeal, a plaintiff stood to gain the amount of sick pay that had been denied to him or her. As this amounted to approximately 2 marks per day, the total amount was normally under 50 marks (though the amounts at stake ranged from 7 to 100 marks). Patients were bargaining for a few marks as well as for bigger amounts. At the same time, plaintiffs also assumed expenses, ranging between 4 and 40 marks. From the point of view of the working-class plaintiff, losing the case a second time meant incurring heavy financial losses: foregoing the sick pay, and paying for two lawsuits.

\section{Outcomes of the Lawsuits}

Altogether the success rate for the members of the sickness funds was rather low: less than a third of the plaintiffs won their case. Of the 99 plaintiffs, 31.3 per cent won, but this includes 8 per cent who were awarded sick pay but had to bear court costs. Around 5 per cent of the plaintiffs withdrew their action. In 2 per cent of the cases the action was dismissed because the time limit for an appeal had expired. The health funds won in about 53 per cent of the cases, perhaps at the expense of their reputation among plaintiffs and their peers. The outcomes of the lawsuits are summarized in Table 4. 
Table 4:

Outcome of lawsuits

\begin{tabular}{lccccc}
\hline $\begin{array}{l}\text { Health fund's reason } \\
\text { for denial of sick pay }\end{array}$ & $\begin{array}{c}\text { Plaintiff } \\
\text { won }\end{array}$ & $\begin{array}{c}\text { Plaintiff } \\
\text { lost }\end{array}$ & $\begin{array}{c}\text { Plaintiff won } \\
\text { partly }\end{array}$ & $\begin{array}{c}\text { Lawsuit } \\
\text { withdrawn }\end{array}$ & $\begin{array}{c}\text { Lawsuit dismissed } \\
\text { because period } \\
\text { expired }\end{array}$ \\
\hline $\begin{array}{l}\text { Plaintiff refused } \\
\text { hospitalization }\end{array}$ & 21 & 39 & 6 & 4 & 2 \\
$\begin{array}{l}\text { Plaintiff delayed entry } \\
\text { to hospital }\end{array}$ & 10 & 12 & 2 & 1 & \\
$\begin{array}{l}\text { Patient left hospital without } \\
\text { due authorization }\end{array}$ & 12 & & & & \\
$\begin{array}{l}\text { Patient did not enter the } \\
\text { right hospital }\end{array}$ & & 1 & & & \\
\hline
\end{tabular}

Patients who refused hospitalization altogether (72, or 72.7 per cent) won the appeal in 29.2 per cent of the cases, and lost in 54.2 per cent. Patients who arrived later or left earlier than expected (altogether 26 or 26.3 per cent) won in 38.5 per cent of the cases and lost in 46.2 per cent. This difference is not very remarkable, but a plaintiff who had completed at least some of the hospitalization required was more likely to win the appeal than a plaintiff who had refused hospitalization altogether.

The most significant factors contributing to a plaintiff's success were favourable opinions from experts, and inconsistency in the health fund's reasons for requiring hospitalization. Marital status could also be a factor, as in some cases the court accepted the arguments of married members. Single persons who had refused hospitalization entirely had the lowest chance of winning the case.

As all these lawsuits were decided in the same court, the reasons for the judgments were very similar. However, matters were quite different in the wider arena of the entire German Reich. The health-insurance periodical, Deutsche Krankenkassen-Zeitung, listed 32 cases brought to court between 1908 and 1914 as a result of disagreements between health funds and their members concerning hospitalization. To enable comparison of the situation in Baden with the jurisdiction in the German Reich, I first summarize the analysis of the Deutsche Krankenkassen-Zeitung.

\section{Jurisdictions Concerning Hospitalization in the German Reich}

The reports on the hearings in the Deutsche Krankenkassen-Zeitung are rather short, normally containing only the description of the issue and the verdict, with very little explanation of the motives of the parties concerned. The cases were considered in both the court of first instance and in the court of appeal. Table 5 shows the causes for the disputes in all 32 cases.

In all 32 cases, the members appeared as plaintiffs because their health fund had not paid the hospital costs or the sickness benefits. As the total number of such cases for this period for the whole German Reich seems unobtainable, it is not possible to speak 


\section{Sylvelyn Hähner-Rombach}

Table 5:

Disputed hospitalization: 1908-1914

\begin{tabular}{lc}
\hline Causes & Quantity \\
\hline $\begin{array}{l}\text { Patient came to hospital as an emergency case, the health fund refused } \\
\text { to pay the costs }\end{array}$ & 6 \\
Patient left the hospital without authorization & 3 \\
Patient left the hospital with the doctor's permission but without the & 4 \\
health fund's permission & 5 \\
Patient went to hospital later than required & 13 \\
Patient refused hospitalization & 1 \\
Patient refused the hospital chosen by the health fund and went to another & 1
\end{tabular}

Source: Deutsche Krankenkassen-Zeitung, 1908-1914.

of a general trend. However, it is easy to conclude that this sort of case occurred frequently. 57

In fourteen cases (43.75 per cent), health fund members won their lawsuits in the court of first instance, and in four cases they won in the court of appeal. This means that 56.25 per cent of the plaintiffs won their suits, ${ }^{58}$ and the remainder had to pay the expenses of the lawsuit as well as forfeiting their sickness benefits.

The health funds won thirteen times in the first instance and three times in the court of appeal. Of the 32 cases, seven ( 21.9 per cent) were brought before a court of appeal: four by members, three by health funds.

There were five lawsuits concerning payment for a hospital stay not ordered by the health fund, and none of them reached the court of appeal. Here the court decisions varied considerably in very similar cases: one case was decided in favour of the member, two cases in favour of the fund, and two cases were settled with the hospital expenses being covered by the fund, and the court expenses by the member. Four of the five cases were true emergencies, and in four of them the patient was referred by a physician, but the health funds, nevertheless, maintained that they should have been consulted before the patient went to hospital. In some of these cases, the health funds asserted, and the courts maintained, that the patient had no legal claim (Rechtsanspruch) to hospital treatment even if the severity of the disease made this necessary. ${ }^{59}$ On the one hand, patients had no right to

\footnotetext{
57 “'Bekanntlich entsteht sehr oft zwischen den Angehörigen einer Krankenkasse und der Krankenkasse selbst Streit darüber, ob die Nichtbefolgung der Einweisung ins Krankenhaus seitens des Kassenmitglieds berechtigt war oder nicht." Deutsche Krankenkassen-Zeitung, 1913, 13: 17. "Da die Kassen im Falle der Weigerung der Patienten [der Krankenhauseinweisung Folge zu leisten-S.H.] diesen fast immer die Krankenunterstützung entziehen, haben die Gerichte in zahlreichen Fällen zu entscheiden". Deutsche Krankenkassen-Zeitung, 1909, 9: 216.
}

\footnotetext{
${ }^{58}$ Of the relevant cases heard before the Verwaltungsgericht Karlsruhe between 1886 and 1914 , only 31.6 per cent were won by members, a settlement was reached in 8.2 per cent; 5.1 per cent abandoned the lawsuit and 2 per cent of the cases were not heard because the plaintiffs failed to meet the deadline.

${ }^{59}$ See ' $[D]$ er Angehörige einer Krankenkasse hat selbst in einem dringenden Falle keinen Anspruch auf Krankenhauspflege', in Deutsche KrankenkassenZeitung, 1912, 12: 278.
} 


\section{Hospitalization in Baden, 1893-1914}

go to hospital without health fund authorization; on the other, they were forced to go to hospital when ordered to by the health fund.

Of the cases concerning early discharge from hospital, the health funds refused to grant sick pay for the time not spent in the institution. Out of seven cases, the health funds won four (including one in the court of appeal), and the member won three (including twice in the court of appeal). One controversial point was whether the patient had the doctor's permission (doctor and patient statements differed) and, if so, whether that permission gave him the right to leave the hospital. Here, the court decisions varied. Some accepted the doctor's permission as a justification for leaving hospital, others did not. ${ }^{60}$ The patients claimed that the doctor's permission authorized them to go home. The courts that agreed with this opinion argued that, for the patient, there was no difference between the permission of a doctor and that of the health fund. Furthermore, in some cases, the regulations of the health fund did not require permission from the health fund itself, as long as the doctor agreed. For some courts, the circumstances dictated to what extent the doctor's opinion regarding hospitalization was taken into account. When the health fund had sent the patient to hospital because he or she was suspected of malingering or contravening the rules, the doctor's authorization was not valid, whether or not the patient was informed of this special condition. For example, a disabled patient who had been sent to hospital because he had repeatedly contravened health fund rules, left hospital with the doctor's permission. The health fund thereupon refused to pay the sick benefits, and the court of appeal agreed in its written judgment: "Normally, a patient who leaves hospital with the authorization of the doctor does not lose the right to sick pay. In this case, however, the permission of the health fund was absolutely necessary, because the health fund had sent the patient to the hospital only because he had not observed the rules." 61

The courts took the view that a married member who had already been hospitalized could be ordered to hospital again, unless his family conditions had changed so fundamentally that a continued stay in hospital was pointless.

The health funds had little chance of winning a case when they had not told the patientwhether married or not-the reason for his or her hospitalization. In these circumstances, the member normally won, because, in the court's opinion, he or she had a right to know the reasons so as to have the means, if necessary, to argue against this measure. ${ }^{62}$ The formalities had to be observed, even for patients suspected of malingering. This also held when the health fund failed to inform the patient himself of the decision: it was not sufficient to inform his wife, for example, about the necessity for hospitalization. A health fund could

\footnotetext{
${ }^{60}$ In two very similar cases, the court of appeal supported the patients' argument that "when the physician at the hospital agreed to the patient's discharge, this cannot be interpreted as being against the will of the sickness fund". Another married patient who was suspected of being a malingerer refused hospitalization after having asked his physician whether he as a married man was obliged to go. The doctor said it was doubtful whether he could be forced to follow the instructions of the sickness fund. The patient then refused hospitalization; the court agreed with him: "When his behaviour
}

was influenced by the information given by the physician, this circumstance must excuse the patient". Deutsche Krankenkassen-Zeitung, 1911, 11: 12,279

${ }^{61}$ Deutsche Krankenkassen-Zeitung, 1911, 11: 96.

${ }^{62}$ In one case, a married member suffering from a lung disease was supposed to go to hospital without knowing the reason for his hospitalization, and therefore refused. The court sided with the patient: the sickness fund was obliged to tell him why he should go. Deutsche Krankenkassen-Zeitung, 1910, 10: 176. 


\section{Sylvelyn Hähner-Rombach}

lose the case if it did not ask the member why he or she had left hospital. In one case, a seriously ill woman left hospital without the permission of either the doctor or the health fund. The health fund did not pay the sick benefits and, when the woman died, it also refused to pay the death benefit. The court of appeal ruled against the health fund, because it had not looked into the woman's reasons for leaving the hospital.

The question of whether hospitalization was necessary or helpful only occasionally affected the decision of the court. In one case, a patient refused hospitalization and, as a result, lost his sick pay. Although it turned out that hospital treatment was not necessary, the court agreed with the health fund. In another case, the health fund ordered hospitalization although the family doctor was against it. Here, the court sided with the patient who had refused to go to hospital. He had the right to treat himself because, in the opinion of a medical expert, the stay in a hospital would have been harmful. There are some other examples in which the health fund ordered hospitalization although the family doctor opposed it. In one case, the health fund wanted a woman suffering from anaemia to go to hospital. Her family doctor opposed this step; another physician, asked by the health fund, was in favour of it. The woman refused hospitalization, and the court agreed with her on the basis of the family doctor's opinion.

It seems that the health funds often applied their rules very rigidly, not showing any understanding of the circumstances that might have led the patient to leave the hospital (for example, the above mentioned case of the mortally ill woman). Similarly, a nineteen-yearold worker who had been in hospital a long time became homesick and even mentally ill. His father agreed that he should return home, and the patient left the hospital without authorization from the health fund, which then refused to pay his sickness benefits. The court took the view that the health fund was right, even though the patient's physical state did not deteriorate at home. In another case, the court ruled in favour of the member: an unmarried patient suffering from lung disease obtained the health fund's permission to return to his parents for three weeks. After this time, the health fund ordered re-hospitalization. The patient sent a medical certificate stating that he could not undertake the journey because of his illness. The health fund then refused to pay the sickness benefits, but the court agreed with the patient: although the health fund had the right to order hospitalization, it was above all committed to taking care of the sick. Another example involved not a health fund, but a social insurance board (Landesversicherungsanstalt) which insisted on the same rules: an orthodox Jewish woman suffering from tuberculosis refused to go to a sanatorium because her religious beliefs required her to eat kosher food, which was not available there. The social insurance board then refused to pay her social insurance pension. The court agreed with the patient: had she entered the sanatorium, she would have suffered an inner conflict that could have seriously harmed her.

As we have seen, the health funds ignored information that the patient had a doctor's authorization to leave the hospital and refused to pay sickness benefits. Courts were generally inconsistent: in very similar circumstances, they sometimes ruled in favour of patients, sometimes in favour of the health funds. The purpose of publishing the cases was to inform the health funds of the precedents. Given the inconsistency of the precedents, however, the only conclusion a health fund could draw from a group of cases such as the one studied here was that anything was possible, as the verdict depended almost entirely on the judge. 


\section{Hospitalization in Baden, 1893-1914}

\section{Conclusion}

From the very beginning the Health Insurance Act was regarded as a charitable act for the benefit of the workforce. The latter was expected to be grateful for this welfare provision in case of illness. Contrary to expectations there were many conflicts between the health insurance companies and their members. The example of hospitalization demonstrates that this alleged benefit had some noticeable disadvantages for the persons concerned; patients argued against their hospitalization, and complained about their experiences with representatives of the health insurance companies, hospital treatment, hospital physicians, panel physicians and family doctors. From these records of the conflicts between members and their health insurance companies we can gain insight into the patients' views of the "benefits" of health insurance in Germany at the turn of the century. In the disputes over hospitalization in this sample, almost all involved persons are represented: courts, administrators of health funds, physicians, patients and-in some casestheir relatives.

The physicians' ongoing efforts at professionalization were not disrupted or slowed by these lawsuits. On the contrary, physicians were and remained the only experts approved by law on questions of health and illness. Patients had to accept that whether they liked it or not. Their only weapon was recalcitrance-with the risk of paying for it. The role of the hospital in the process of medicalization was also strengthened by the insurance legislation. Advances in medical science and improvements in quality (staff, facilities, equipment)—which were partly a response to criticism by patients and health insurance companies $^{63}$-increasingly made hospitals centres of medical expertise. But the lawsuits show, nevertheless, that medicalization, professionalization, and disciplining did not work from the top down. Patients played an active role in these processes, which can be best seen in their responses to the health funds' attempts at disciplining them. First, the numbers of lawsuits did not decline within the period even though the plaintiffs were not very successful. Second, there was a amendment to the Health Insurance Act in 1903 which allowed health funds to extend their benefits-for example to grant members living alone an allowance during hospitalization up to a quarter of their daily wage. This was a concession to this group of members, even if it was only a discretionary provision depending on the finances of the individual health fund.

One open question cannot finally be answered: how did the health fund members obtain the information and perhaps the assistance they needed to sue large organizations such as health funds? Presumably, the written judgment of the court of first instance contained a passage drawing attention to the possibility of appealing the ruling within a given period. Twenty plaintiffs had a lawyer or a trade unionist, nine sued in forma pauperis. The majority of seventy plaintiffs brought their cases either on their own or with some sort of assistance. There are some hints as to what form this may have taken. Word-of-mouth, for example, helped many members to learn of their rights under the Health Insurance Act. A bricklayer pointed out: "I poured out my troubles to my colleagues, stressing that hospitalization would be especially hard given my domestic circumstances, which I described.... My

\footnotetext{
${ }^{63}$ See note 24 above for the boycott of the Berlin Charité.
} 


\section{Sylvelyn Hähner-Rombach}

colleagues then explained to me that married members need not to go to hospital, and gave some similar cases as proof." ${ }^{64}$ I think we can assume that the members discussed their conflicts with the health insurance company in their communities and in this way obtained at least moral support in their fight against the health fund. The attitudes of this underclass,

their general readiness to enter legal dispute, and the procedure of going to court remain to be explored.

${ }^{64}$ GLA Karlsruhe, Bestand 239, Nr. 7202. 